This is an Accepted Manuscript of the following book chapter: Kennell, James (2013) After the crisis: cultural tourism and urban regeneration in Europe In: Smith, Melanie and Richards, Greg, (eds.) The Routledge Handbook of Cultural Tourism. Routledge, Abingdon, UK, pp. 317-323. ISBN 978-0-415-52351-6

\title{
After the crisis: Cultural Tourism and Urban Regeneration in Europe
}

James Kennell, University of Greenwich Business School.

Over the last three decades urban regeneration and tourism in Europe have become most closely linked through the phenomenon of cultural regeneration, an approach to urban development that has become a significant part of the suite of approaches to regeneration used by governments and regeneration agencies (Evans 2005, Smith 2007a, Vickery 2007). Landry (2000) argues that the reason why some post-industrial cities have prospered since the economic crises of the 1970s and 80s is precisely because they made this turn to cultural investment and creativity in the context of urban decline and renewal. Evans highlights the potential for cultural development as a mode of action within the policy arena as one of the few available strategies that can engage with globalisation and "capture the twin goals of competitive advantage and quality of life" (2005: 960), perhaps helping to explain its current popularity. Grodach \& Loukaitou-Sideris (2007) reinforce this perspective, highlighting how cities pursue cultural development strategies to catalyse inward business investment, increase consumption by residents and tourists, improve city image and enhance local quality of life.

In the context of urban regeneration, culture is defined broadly, but can involve elements or combinations of: 
- Architecture

- Heritage buildings and attractions

- Visual and performing arts

- Festivals and events

- Tourism development

- Entertainment and leisure complexes

- "culture as a way of life" (Smith 2007b: 2)

These elements are valorised and then commercialised through cultural tourism, which provides the marketplace of consumption necessary for the economic model that underpins cultural regeneration to be sustainable. This model has four components, shown in figure 1 , each of which has been significantly affected by the economic crisis that has been evolving in Europe since 2008. Each of these components will be analysed in turn below.

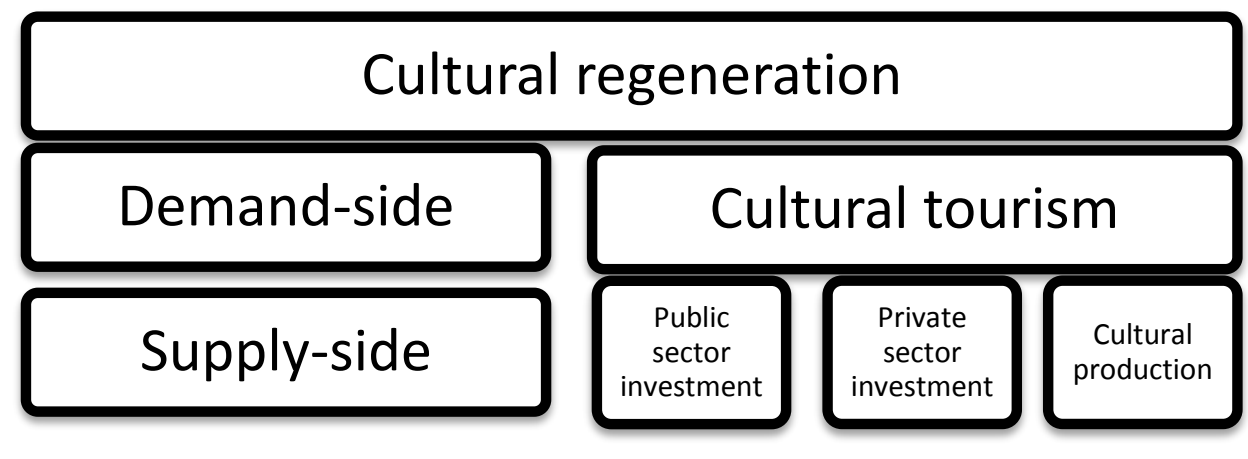

There are three key elements on the supply side for cultural regeneration projects which work to create the tourism products and services for the cultural tourism market. The first of these 
is public sector investment. Many cultural regeneration schemes have relied on significant levels of state funding for key infrastructure and cultural facilities. For example, in the late1990s, the councils of the cities of Newcastle and Gateshead in the North-East of England began to work together on a cultural regeneration strategy that was to bear fruit in 2002 with the opening of a major new contemporary art museum and an international-standard concert hall in a previously run-down part of the cities' formerly vibrant industrial areas on the Tyne river. This scheme has led to the growth of the cities' night time economies (Miles 2010) and helped to kick-start economic growth in the creative industries (Minton 2004). The value of tourism to the regional economy in Newcastle and Gateshead grew by $30 \%$ year-on-year in the first five years after the new Baltic Gallery opened in 2002 (NEBG 2008). The investment required to develop this programme of cultural interventions in regeneration was led by the public sector, with over $£ 200 \mathrm{~m}$ of state funding supplied by a consortia of public bodies from local government, regional development and the cultural sector (One North East 2011).

Attracting new private sector investment is a key driver of contemporary regeneration. The metropolitan area of Lille and its surrounding towns was suffering from the negative consequences of economic restructuring and deindustrialisation when the decision was taken to regenerate the city-region in the 1990s. This regeneration has had significant cultural components, and was driven by the successful bid of Lille to become European Capital of Culture in 2004, which had the newly refurbished Palais des Beux Arts as its centrepiece venue. A town in the Lille metropolitan area, Roubaix, had previously been regarded as the 'worst town in France' (Cadell et al 2008) and culture was central to its regeneration plans, including 'la piscine' a renovated art deco public baths, now a national museum of art and industry and 'la conditione publique', a former industrial building from the region's once 
dominant textiles industry, now converted into a cultural hub with recording facilities, a concert hall and theatre and exhibition spaces. The initial regeneration programme in Lille, which occurred at the time of the opening of the cross-channel Eurotunnel terminal in the city, was funded mainly from the private sector (FR3.5bn from FR5bn in total) and the city region has used public funding to leverage private sector investment as the regeneration has continued. The private sector has led on the creation of new business and science parks, creating new industrial sectors populated by firms who have been attracted by the improved quality of life and renewed image of the area, including Haute-Bonne which is home to sixty scientific research laboratories. Inward investment and job creation in the Lille region has dramatically increased, with $15 \%$ of new jobs coming from high value knowledge industries (Bacon et al 2008).

The third element of the supply side system for cultural regeneration is cultural production. This can involve the direct production of cultural goods and experiences by individuals, groups of producers and businesses or indirect provision in the shape of exhibitions, touring performances, retail and other methods of supplying non-locally produced cultural output. Undervaerket in Randers, Denmark's sixth largest city, is an example of a cultural regeneration project that has cultural production as its main driver. Randers has endured a long period of economic decline as traditional industries associated with shipping and clothing manufacture have shrunk. The city government also identified difficulties in the integration of newly arrived migrants into areas already suffering from socio-economic problems. Part of the solution to this twin dilemma has been Undervaerket, a bazaar-style cluster of shops, market stalls, cultural and educational spaces (Undervaerket 2011: home). This new creative space brings craftspeople, including jewellers, glass blowers, graphic artists, ceramic artists, textile printers and weavers into close proximity to each other and to a 
concentration of ethnic businesses and facilities. Many of the projects in Undervaerket have involved using cultural production to break down barriers between immigrant and indigenous groups and new businesses have started up capitalising on the presence of imported craft traditions. The ERDF-funded UrbAct programme found that "Its strength lies in the way it combines regeneration, job creation, training, small business support and tourism while at the same time harnessing cultural diversity to a cultural industries strategy." (Udix Alep 2005: underverkaet_ws7).

Uniting all three of these examples is the demand side aspect of cultural regeneration: cultural tourism. It is through this form of tourism that cultural regeneration schemes derive a vital source of ongoing revenue, leading to business growth and increased local taxation. Cultural tourism also provides a shop-window for promoting inward investment and relocation by businesses and individuals. Cultural tourism is seen as both a 'good' form of tourism in that it promotes sustainability and intercultural communication, and as a high-value industry because of the high-spending tourists who take part in it (Cengiz et al 2006). This combination of sustainability and economic impact makes cultural tourism an attractive tool for policy makers seeking to regenerate an area through diversification and stimulation of its economy, a key aim of regeneration projects. In addition, the achievement of more wideranging outcomes is predicated on the knock-on benefits of income streams that have cultural tourism and private sector growth at their base.

The global financial crisis that began in 2008 has had significant impacts on the global tourism industry. Tourism has experienced greater falls in spending than other industries, impacting negatively on the economic contribution that tourism makes to destinations (Sheldon \& Dwyer 2010). By the first quarter of 2009, global tourism arrivals had dropped 
by $8 \%$ and in Europe, international arrivals were down by $10 \%$ (Smeral 2010). Although there has been some limited recovery since 2009, especially on inbound trips to the EU and in low cost markets (Eurostats 2011), internal demand is likely to remain suppressed by the effects of the crisis in the Euro zone that is producing growing unemployment and significant drops in both public and private sector investment. Public sector austerity and private sector retrenchment is creating a crisis for cultural regeneration in Europe as a wide debate takes place about the value of public spending in areas of culture, tourism and regeneration, at the same time as private investment in tourism and regeneration is dropping and the lucrative cultural tourism market is shrinking. The one element of the supply-side that does not bear a direct relationship to the economic crisis is cultural production, calling into question Kunzmann's assertion that "Each story of regeneration begins with poetry and ends with real estate." (cited in Evans 2005: 959). After the crisis, poetry may be the only reliable component of cultural regeneration in Europe.

If it is cultural production that will be the driving force of cultural regeneration in the coming years, then the question must be asked of what this might look like in terms of its impact on the urban environment and what relationship, if any, this will have to cultural tourism in Europe? The story of massive cultural investment in regeneration that had its beginnings in 1997 with the Guggenheim Museum in Bilbao may well have come to an end with the 2011 opening of Turner Contemporary in Margate, which benefited from $£ 25 \mathrm{~m}$ of EU and UK government money and which is intended to drive the regeneration of a prominent and now very deprived example of England's faded seaside towns. The gallery's 156,000 visitors in its first twelve weeks (Kent News 2011) have undoubtedly brought new money into the town, but, as with all models of cultural regeneration based on trickle-down economics, the future success of this intervention is precariously hitched to the economics of cultural tourism. In 
future, we should expect to see fewer large capital projects like these in cultural regeneration but instead, in those areas where the cultural route is valued and supported, higher levels of bottom-up activity, artist-led interventions in the urban fabric and time-limited, event-driven approaches to cultural development, where cultural tourism is a more proportional aspect of the mix that sustains these projects. An example of how cultural regeneration can be driven from the bottom-up, with minimal state or private investment, but maintaining the positive impacts of the cultural approach is the People's Republic of Stokes Croft in Bristol, UK.

\section{'Case Study start'}

\section{Case Study: The People's Republic of Stokes Croft, Bristol, UK}

Stokes Croft is the informal name for an area within Bristol, in the West of England, that has suffered from the historical decline of the city as an industrial and trading hub, but that has not benefited directly from the city's recent redevelopment as a financial and retail centre of regional importance. Stokes Croft is a diverse area that has seen high levels of immigration as well as playing host to transient populations of students, artists and squatters.

The People's Republic of Stokes Croft (PRSC) was formed in 2007 to bring together people from the local community to promote a positive sense of place for the area and to improve both its streetscape and its day-to-day life through the creation of a bottom-up cultural quarter. This is being achieved by groups of activists, individuals, residents and visitors, without dependence on public or private investment, building on the reputation of the area as creative and diverse, especially its international reputation for (often illegal) street art. Although the state, the third sector and private companies have been engaged in specific projects, the PRSC draws on local resources to achieve its aims and strongly resists attempts 
to direct the project from the outside. The aims of the PRSC align its objectives with the aims of cultural regeneration projects across Europe, which have attempted to link quality of life, creativity, tourism and sense of place:

"Our aim as a community will be to make the whole area a pleasure to visit, a place where people want to come and spend time... a place where people want to be. There is an enormous amount of traffic, vehicular and pedestrian, that passes through Stokes Croft every day, and our aim must be to make that experience as welcoming and as pleasant as possible. We will do this by attending to every aspect of the visual amenity of the area, by making the place feel loved, by positive energy. Stokes Croft as an area of outstanding creativity and individuality, as a gallery, as a sculpture, as a destination.” (PRSC 2008: 1)

The PRSC has developed an artist-led regeneration plan (PRSC 2008) which contains details of specific short, medium and long-term projects, but recent projects in the area have included:

Co-exist - a renovated 55,000sqft former office building, taken over by a Community Interest Company and now home to a community kitchen, a restaurant, artist studios and a live music venue. This is a community managed project that has attracted private investment from a property developer (Co-exist 2011) 
Stokes Croft Streefest - organised in partnership with the Bristol Festival Community Group, this is a one day festival celebrating local creativity, diversity and inclusiveness. It is a preceded by a week of community action to improve the area and includes music, art, theatre, stalls, children's activities and workshops (Stokes Croft StreetFest 2011)

Visit Stokes Croft -This is an independent tourist brand for the area with the tagline 'Bristol's Cultural Quarter'. The website promotes the attractions of the area, primarily the high volume and world-leading quality, street art that adorns the many abandoned buildings, as well as giving useful tourist information such as directions, food and drink and contact details (Visit Stokes Croft 2011)

Figure 2 - Visit Stokes Croft poster

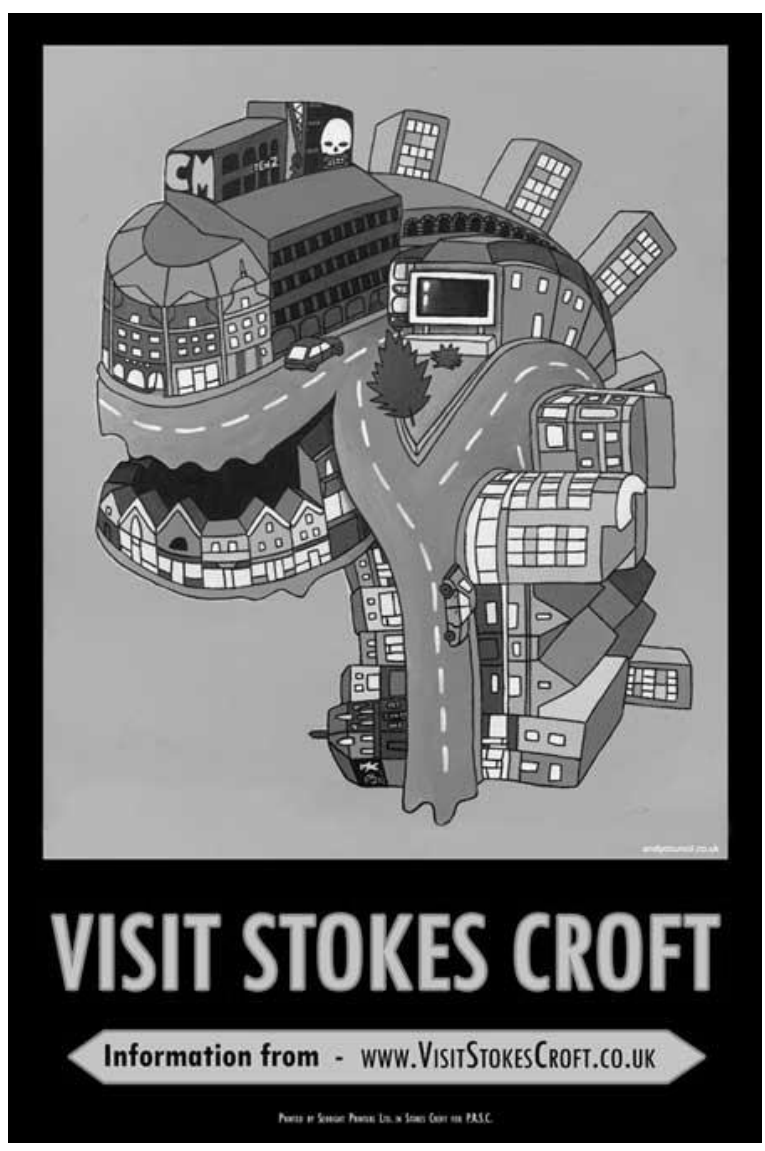

'Case Study end' 
As Europe struggles to return to economic stability and growth over the coming decade, the rhetoric of cultural regeneration will be sorely tested by the lack of public and private investment available to drive it from the top-down. Clearly, not everywhere can follow this model of bottom-up activism in cultural regeneration, but the example of Stokes Croft shows how the aims of cultural regeneration strategies can be achieved without the involvement of celebrity architects, landmark galleries and huge levels of investment. Regeneration that is driven by cultural production and producers, such as is taking place in Stokes Croft, creates new resources for cultural tourism, but these resources may not always fit neatly into the strategies of Destination Marketing Organisations and local authority planners. For cultural tourism to continue to impact on urban regeneration in times of austerity will require tourism and regeneration professionals to develop new ways of working in partnership with cultural producers at the street and community levels, because without these relationships a major driver of regeneration will be lost.

\section{References}

Bacon, N., Faizullah, N., Mulgan, G. \& Woodcraft, S. (2008) Transformers: How local areas innovate to address changing social needs, London: NESTA

Cadell, C., Falk, N. \& King, F. (2008) Regeneration in European Cities, York: Joseph Rowntree Foundation 
Cengiz, H., Ery1lmaz, S. S. \& Ery1lmaz, Y. (2006) “The Importance of Cultural Tourism in the EU Integration Process", paper given at the 42nd I SoCaRP Congress, 14-16 September, Yildiz, Turkey

Co-exist (2011) home [online]

Available from: http://coexistcic.squarespace.com/

Accessed $24^{\text {th }}$ January 2011

Evans, G. (2005) “Measure for Measure: Evaluating the Evidence of Culture's Contribution to Regeneration" in Urban Studies, 42: 5/6, 959-983

Eurostats (2011) Winter Season Tourism Trends 2010-11, Luxumbourg, European Comission

Grodach, C. \& Loukaitou-Sideris, A. (2007) “Cultural Development Strategies and Urban Revitalisation: A survey of US cities" in International Journal of Cultural Policy, 13:4, 349370

Kent News (2011) Turner Contemporary Welcomes its $156000^{\text {th }}$ visitor [online]

Available from:

http://www.kentnews.co.uk/mobile/news/turner_contemporary_welcomes_its_156_000th_vis $\underline{\text { itor_1_969560 }}$ 
Accessed $24^{\text {th }}$ January 2012

Miles, S. (2010) Spaces for Consumption, London: Sage

Minton, A. (2004) Northern Soul: Culture, creativity and quality of place in Newcastle and Gateshead, London: DEMOS / RICS

NEBG (2008) Tourism growth supports jobs in the north east [online]

Available from: http://www.nebusinessguide.co.uk/news/art/194/Tourism-growth-supportsjobs-in-North-East.htm

Accessed $23^{\text {rd }}$ January 2012

One North East (2011) Culture [online]

Available from: http://www.onenortheast.co.uk/place/culture.cfm

Accessed $23^{\text {rd }}$ January 2011

PRSC (2008) Overall game plan for Stokes Croft, Bristol: PRSC

Sheldon, P. \& Dwyer, L. (2010) "The Global Financial Crisis and Tourism: Perspectives of the Academy" in Journal of Travel Research, 49:1, 3-4 
Smeral, E. (2010) "Impacts of the World Recession and Economic Crisis on Tourism: Forecasts and Potential Risks" in Journal of Travel Research, 49:1, 31-38

Smith, M. (2007a) “Towards a Cultural Planning Approach to Regeneration” in Smith, M. (ed.) Tourism Culture and Regeneration, Wallingford: CABI, 1-11

Smith, M. (2007b) "Conclusion” in Smith, M. (ed.) Tourism Culture and Regeneration, Wallingford: CABI, 175-178

Stokes Croft StreetFest (2011) $\underline{\text { Home }}$ [online]

Available from: http://stokescroftstreetfest.wordpress.com/

Accessed $23^{\text {rd }}$ January 2012

Udix Alep (2005) Quartiers en Crise [online]

Available from: http://www.qec-eran.org/urbact/underverkaet_ws7.htm

Accessed $23^{\text {rd }}$ January 2012

Undervaerket (2011) Forside [online] 
Available from: http://www.undervaerket.dk/Forside.html

Accessed $23^{\text {rd }}$ January 2012

Vickery, J. (2007) The Emergence of Culture-led Regeneration: A policy concept and its

discontents, Centre for Cultural Policy Studies Research Paper No.9, University of Warwick

Visit Stokes Croft (2011) Visit Stokes Croft [online]

Available from: http://visitstokescroft.wordpress.com/

Accessed $24^{\text {th }}$ January 2011

$(2,822$ words $)$

Further Reading

Florida, R. (2010) The Great Reset: How New Ways of Living and Working Drive Post-crash Prosperity, New York: Harper Collins

Written by the researcher who coined the term 'the creative class', this book covers both the causes of the current economic crisis and explores a set of solutions that can be applied in cities to promote new growth.

Miles, S. (2010) Spaces for Consumption, London: Sage

This book looks at the phenomenon of the modern, globalised city and questions the place of culture and consumption within it. It has chapters on mega-events, theming and retail which 
analyse the importance of these aspects of tourism for understanding the development and regeneration of urban areas.

Smith, M. (ed.) (2007) Tourism Culture and Regeneration, Wallingford: CABI

This edited collection contains a range of contributions that vary from the strategic and conceptual to the very practical, and are based on a wide variety of international case studies.

Throsby, D. (2010) The Economics of Cultural Policy, Cambridge: CUP

A very accessible cultural economics text for non-specialists that includes sections on the role of culture in urban and regional development and also on the links between tourism, cultural tourism and economic development. 


\section{Biographical Note}

James Kennell is the Director of the Economic Development Resource Centre at the University of Greenwich Business School, where he is also Senior Lecturer in Tourism and Regeneration. 